\title{
パルス通電焼結法によるベアリング研削加工屑の粉末成型†

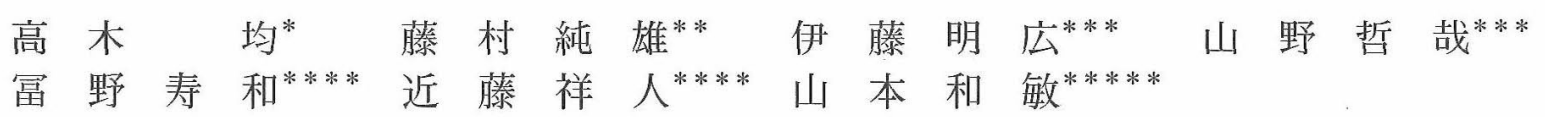 \\ Sintering for Grinding Swarf of Bearing Steel by Pulsed Electric Current Sintering
}

\author{
by \\ Hitoshi Takagi ${ }^{*}$, Sumio Fujimura ${ }^{* *}$, Akihiro Ito ***, Tetsuya Yamano ***, \\ Hisakazu Tomino $^{\text {**** }}$, Yoshihito Kondo ${ }^{\text {**** }}$ and Kazutoshi Yamamoto ${ }^{* * * * *}$
}

This paper deals with sintering behavior of grinding swarf of bearing steel, which abundantly discharged while ball or roller bearings are manufacturing. The grinding swarf is investigated whether it is possible to use as $\mathrm{P} / \mathrm{M}$ raw materials applied to machinery parts. Two kinds of sintering processes were used as a powder forming method, that is pulsed electric current sintering (PECS) and vacuum sintering (VS). The effects of sintering temperature and pressing pressure in the sintering on their mechanical properties and microstructure were evaluated. The density for PECS materials was higher than that for VS materials. In addition, the bending strength for PECS materials with high density was extremely higher than that for VS materials. It is concluded that the PECS is a suitable sintering method for the grinding swarf to get high density and high strength materials.

Key words : Pulsed electric current sintering, Grinding swarf, Bearing, Consolidation, Density, Bending strength

\section{1 緒言}

現在，ベアリングメーカーから大量のベアリング研削 加工首が排出されている。このベアリング研削加工屑は 研削スラッジとも呼ばれ，未熱处理状態の高炭素クロム 鋼（SUJ2）をアルミナ系砥石で研削加工する際に発生し， 加工屑だけでなく砥石から欠け落ちた砥粒や，酸化物， 研削油，水分なざを含んでいる。 この研削加工屑は，べ アリングメーカーから年間数万トン以上排出されているに もかかわらず，元のほぼ全量が処理業者を通して産業廃 蓑物として埋め立て処理もしくは溶解処分されている。し かし近年では，地球環境問題などの面から埋め立てをす 当場所が激减して拁り, 早急な対策が求められている.

そこで我々はリサイクルの一方法として，ベアリング 研削加工屑がミクロンオーダーの微細粉末であることに 注目し，粉末治金の原料粉末として再利用することを考 光た。しかし研削加工屑の発生時すなわち加工時に, 新 たに現れた新生面での酸化反応により加工屑の表面は薄 い酸化皮膜で覆われているため, 焼結特性が悪いことが 予想される。このため本研究では，研削加工屑に対して 近年注目を浴びているパルス通電焼結法 (Pulsed Electric Current Sintering, 以下 PECS) ${ }^{2) \sim 10)}$ を適用した。この PECS 法は，パルス通電を用いた加圧焼結法の一種であ
り，試料とダイに大電流 ON-OFF 直流パル大を流すこと により急速加熱し，同時に一軸加圧して試料を焼絬する 方法であり，金属のみならず，セラミックス，年金属間化 合物)などに代表される難焼結材料の短時問焼結を可能 にする新しい焼結方法である。そこで，PECS 法により 研削加工屑の固化成型を行い, 真空焼結法（Vacuum Sintering，以下 VS）との比較を通して PECS 法の有効性

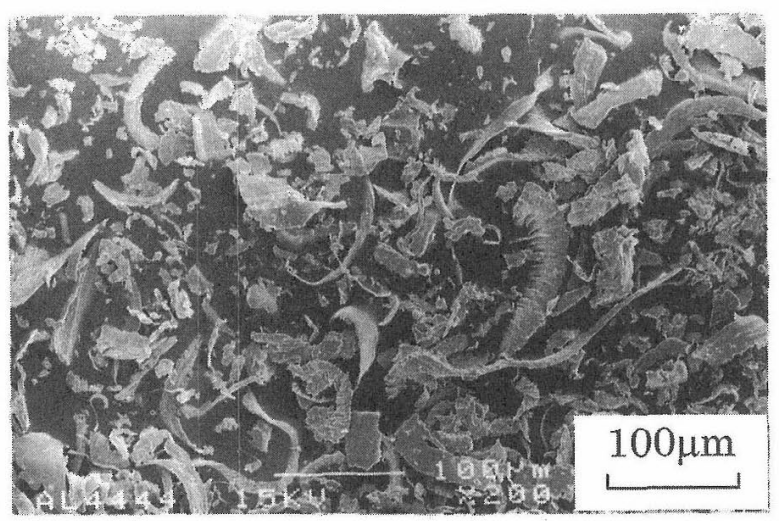

Fig. 1. Typical SEM micrograph of grinding swarf of bearing steel.

\footnotetext{
$\dagger$ 原稿受理 平成 14 年 7 月 3 日 Received July 3, 2002

* 正 会員 徳島大学工学部機械工学科 广770-8506 徳島市南常三島町, Dept. of Mech. Eng., The Univ. of Tokushima, Minamijosanjimacho, Tokushima, 770-8506

** 徳鳥大学大学院丁.学研究科エコシステム工学専攻 キ770-8506 徳島市南常二.島町, Dep. of Ecosystem Eng., Graduate School of Eng., The Univ. of Tokushima, Minamijosanjima-cho, Tokushima, 770-8506

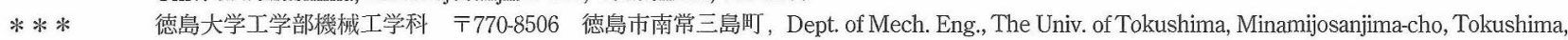
770-8506

****＼cjkstart香川県産業技術センター =760-8031 高松市覑東町, Kagawa Pref. Industrial Tech. Center, Goto-cho, Takamatsu, 760-8031

***** ヨコタコーポレーション(侏) テ779-3306 德島県麻植郡川島町学, Yokota Co. Ltd., Oe-gun, Tokushima, 779-3306
} 


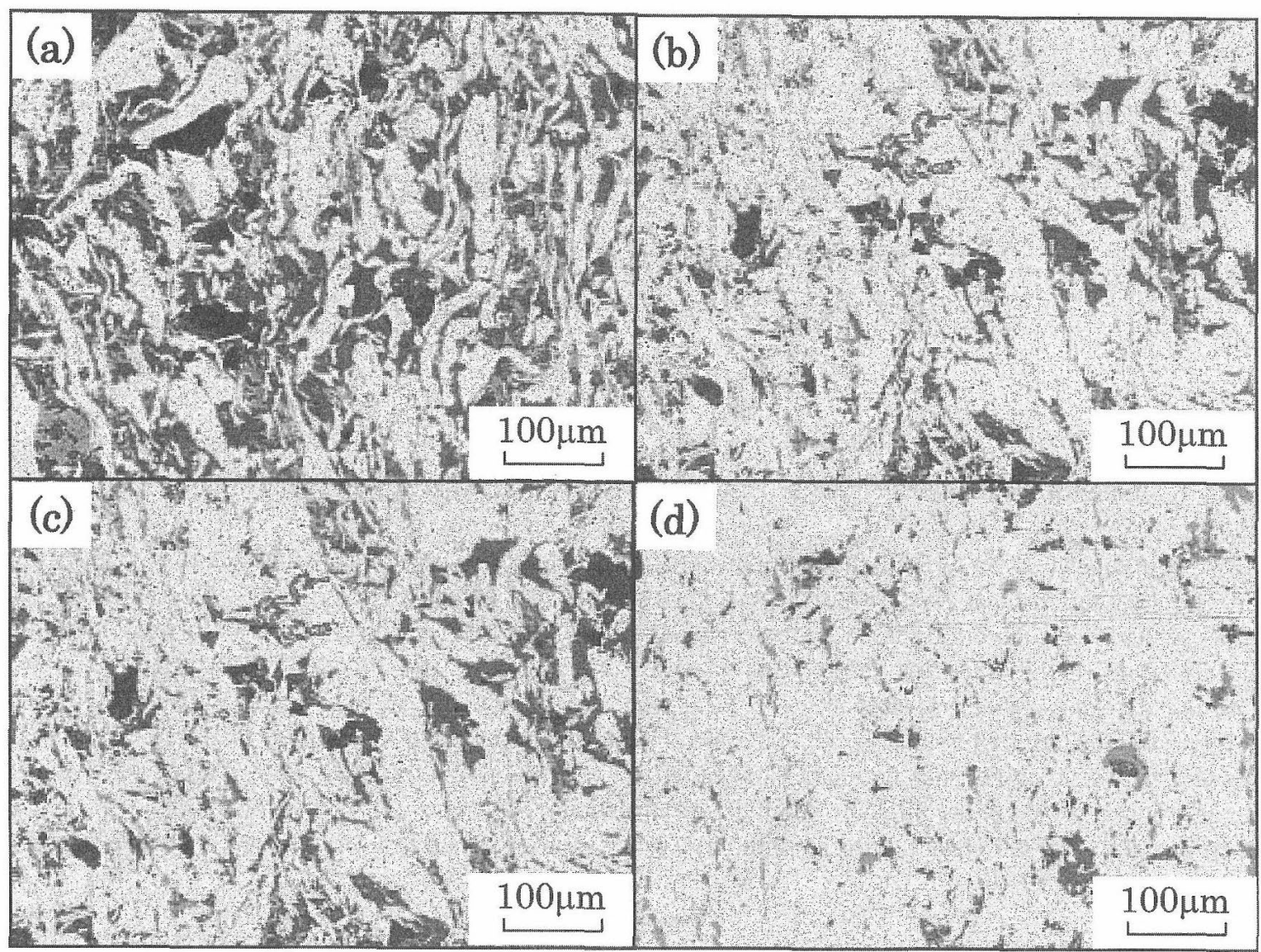

Fig. 2. Microstructures of PECS samples sintered at $30 \mathrm{MPa}$ and at (a) $500^{\circ} \mathrm{C}$, (b) $600^{\circ} \mathrm{C}$, (c) $700^{\circ} \mathrm{C}$, and (d) $800^{\circ} \mathrm{C}$.

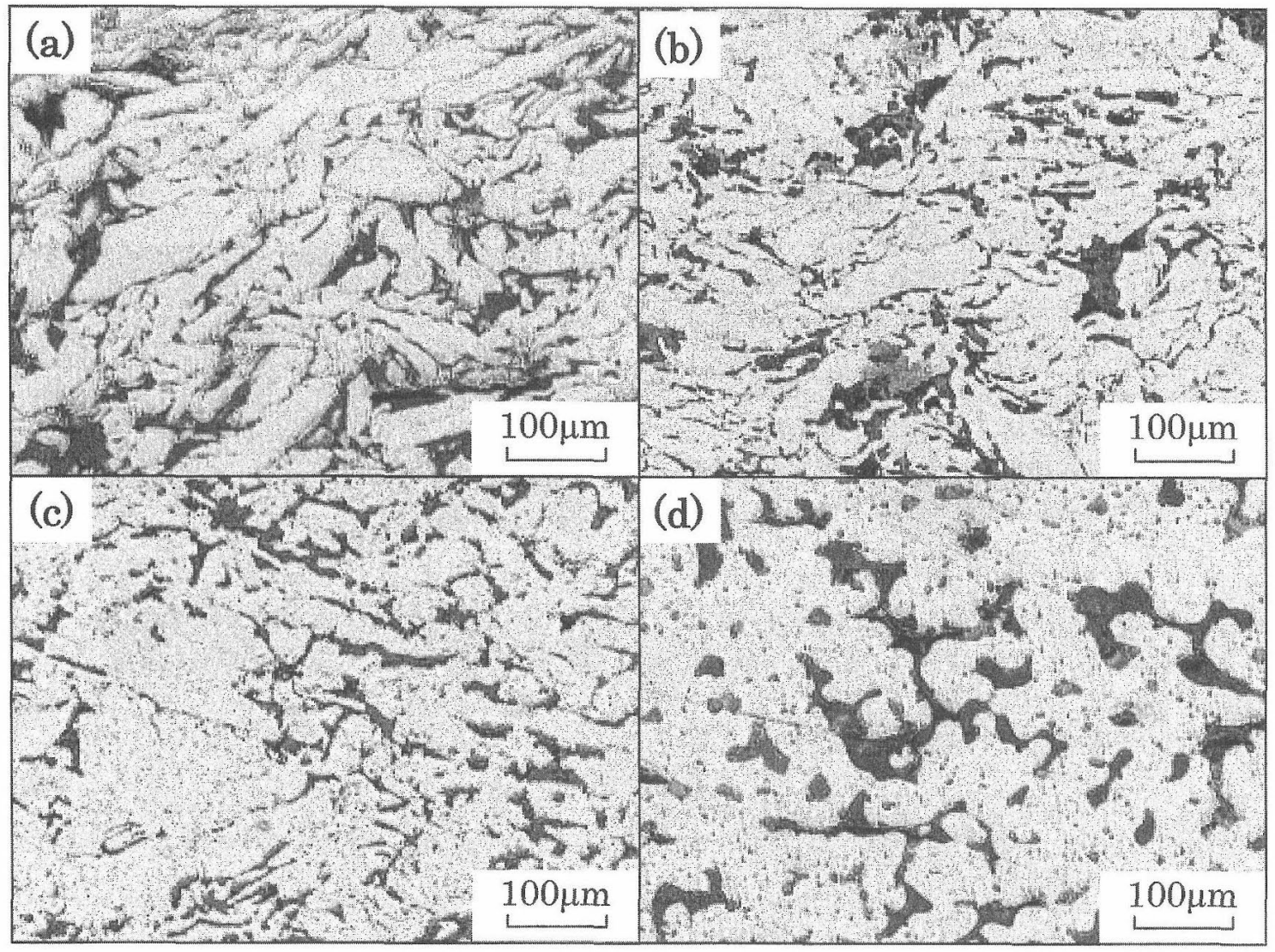

Fig. 3. Microstructures of VS samples pressed at $588 \mathrm{MPa}$ and then sintered at (a) $1100^{\circ} \mathrm{C}$, (b) $1200^{\circ} \mathrm{C}$, (c) $1300^{\circ} \mathrm{C}$, and (d) $1400^{\circ} \mathrm{C}$. 
について調査した。加えて，ベアリング研削加工屑の固 化特性ならびに固化成型体の強度特性を評価し，この研 削加工屑の焼結用素材としての可能性について検討した。

\section{$2 \cdot 1$ 実験材料の作製方法}

$$
2 \text { 実 験 方 法 }
$$

温水で 5 倍に希釈した洗浄剤（エキストラン MA01） を用いて研削加工屑の洗浄を行った。爷の後大気中で $110^{\circ} \mathrm{C} \times 3$ 時間の乾燥処理したものを原料粉末とした. 原料粉末の SEM 写真を Fig. 1 に示す．切削加工屑と同 様に, 流れ形, せん断形, むしり形と呼ばれる形状の切 り屑が見られる。 また，この研削屑には加工中に研削砥 石から脱落した砥粒が含まれている。

\section{$2 \cdot 2$ PECS 法による成型}

PECS 処理には放電プラズマ焼結機（SPS-1030，住友 石炭鉱業(侏製）を使用した。高純度黒鉛製モールド中に 原料粉末を均等に充填し, $1 \times 10^{-1} \mathrm{~Pa}$ 程度の真空下で, 成型圧力 $10 \sim 30 \mathrm{MPa}$, モールド温度 $500 \sim 800^{\circ} \mathrm{C}$, 保 持時間 3 分の条件で PECS 処理を行った。 なお，実際の 焼結温度は測定していないが, 冨野ら ${ }^{8)}$ が報告している ように，モールド温度よりも約 $100^{\circ} \mathrm{C}$ 高くなっていると 考えられる。

\section{$2 \cdot 3$ VS 法による成型}

研削加工屑をプレス機で一軸成型した後，真空熱处理 炉を使用して焼結を行った，成型は， $\phi 40 \mathrm{~mm}$ の金型を 用いて室温で $196 \sim 588 \mathrm{MPa}$ の圧力で行った。焼結は温 度 $1100 \sim 1400^{\circ} \mathrm{C} \times 2$ 時間 $\left(2 \times 10^{-3} \mathrm{~Pa}\right)$ の条件で行った。

\section{$2 \cdot 4$ 曲げ強度試験}

曲げ強度は，インストロン製万能材料試験機 (Model 5567）を用いて 3 点曲げ試験法により求めた。試験は支 点間距離 $30 \mathrm{~mm}$, クロスヘッド速度 $0.5 \mathrm{~mm} / \mathrm{min}$ の条件 で行った.

\section{3 実験結果および考察}

\section{$3 \cdot 1$ 焼結体の組織及ぼす焼結条件の影響}

圧力 $30 \mathrm{MPa}$, 温度 $500 \sim 800^{\circ} \mathrm{C}$ で尭結した PECS 材と $588 \mathrm{MPa}$ で成形した後, $1100 \sim 1400^{\circ} \mathrm{C}$ で真空焼結した VS 材の内部組織写真をそれぞれ Fig. 2, Fig. 3 に示す. $500^{\circ} \mathrm{C}$ で作製した PECS 材の内部には多くの気孔が存在し ているが，焼結温度が上昇するにつれて気孔の量が少な くなり，緻密化が促進している様子が伺える。この様な 緻密化の促進はアトマイズ鋳鉄粉でも報告されている. 方，VS 材では，焼結温度が上昇しても気孔率の減少は

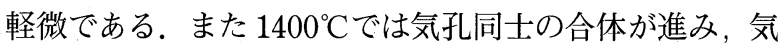
孔の形状は丸みを帯びるようになることがわかる.

\section{$3 \cdot 2$ 焼結体の密度に及ぼす焼結条件の影響}

PECS 材と VS 材の密度と成型圧力, 焼結温度との関 係をそれ艺れ Fig. 4，Fig. 5 に示す。VS材の密度は PECS 材の乞れと比較して明らかに低く，また焼結温度 による高密度化傾向が見られない。一方，PECS 材の密 度は $3.6 \sim 6.8 \mathrm{~g} / \mathrm{cm}^{3}$ となり, 試料作製条件を選択するこ とによって密度を幅広く変化させることが可能であるこ とがわかる。 今回は, 型に使用した材料の耐熱性の制約 から $800^{\circ} \mathrm{C} \times 30 \mathrm{MPa}$ という条件までしか PECS 処理が 行えなかったが，より高温，高圧条件で PECS 处理を行 うことにより，さらに高密度の材料が得られる可能性が Fig. 4 から示唆される.

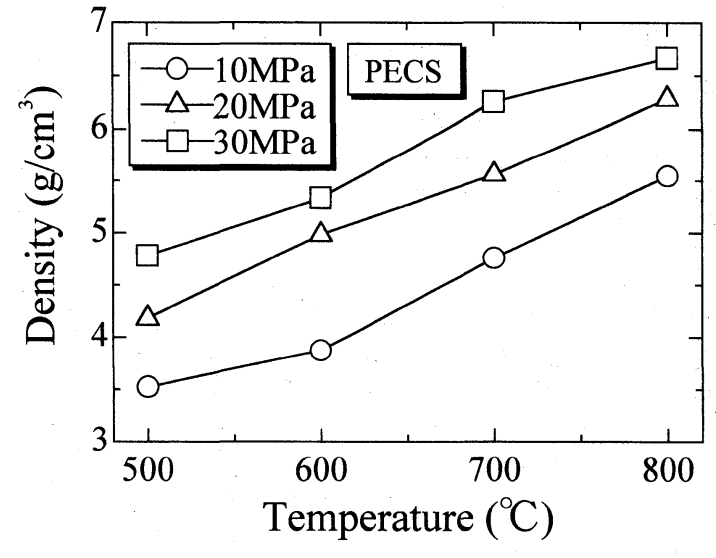

Fig. 4. The variation of the density with processing temperature for PECS specimens.

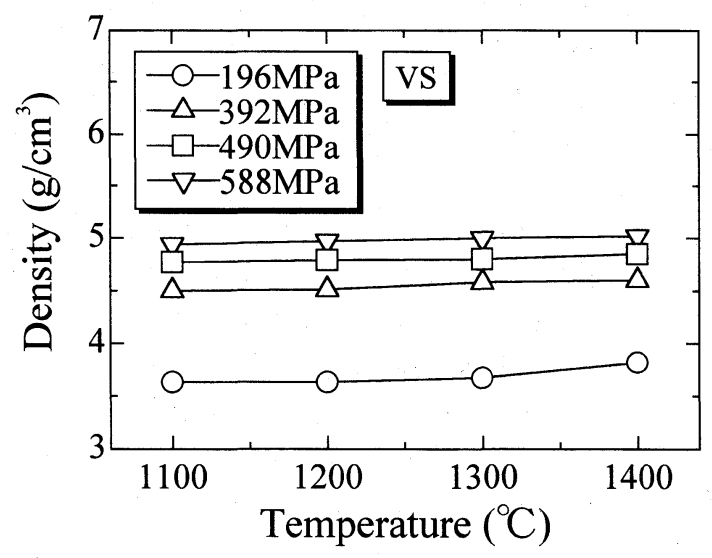

Fig. 5. The variation of the density with processing temperature for VS specimens.

\section{$3 \cdot 3$ 焼結体の曲げ強度に及ぼす焼結条件の影響}

種々の条件で作製した PECS 材と VS 材の 3 点曲げ強 度をそれぞれ Fig. 6, Fig. 7 に示す. PECS 材の曲げ強 度は, 成型圧力, 焼結温度に強く依存していることがわ かる，すなわち，密度に対する焼結条件の影響と同様に PECS 材の曲げ強度も密度が大きくなるにつれて増大し ている. PECS 材の最大曲げ強度は $600 \mathrm{MPa}$ 以上に達し， 機械構造用焼結材として適用可能な静的強度を有するこ とがわかる。

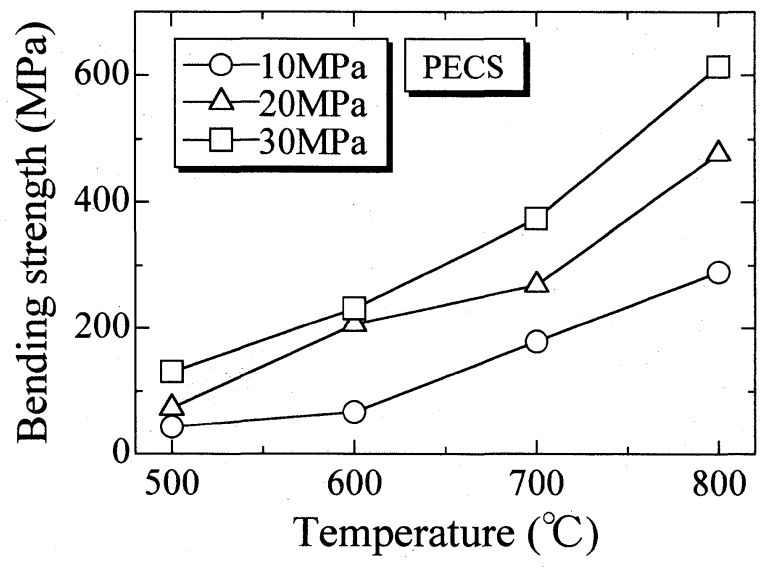

Fig. 6. The relationship between bending strength and processing temperature for PECS specimens. 


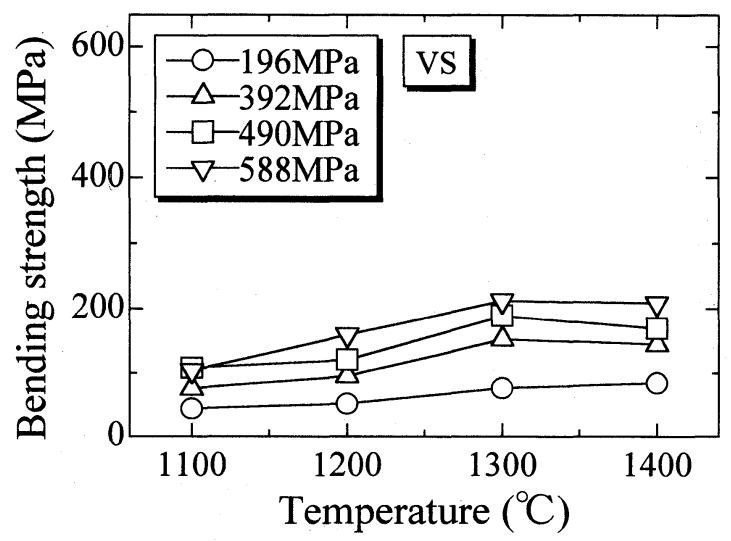

Fig. 7. The relationship between bending strength and processing temperature for VS specimens.

一方, VS 材の強度の焼結温度と成型圧力の依存性は 小さく, 焼結温度 $1100 \sim 1300^{\circ} \mathrm{C}$ にいて曲げ強度の増 加の傾向が若干見られるが，1300〜 $1400^{\circ} \mathrm{Cではほとん}$ ど変化していない. PECS 材と比較してVS 材は低強度 であることが分かる。

PECS 材と VS 材の両方の曲げ強度と気孔率との関係 をFig. 8 に示す.この図より両材の曲げ強度は気孔率に 依存していることがわかる．鉄鋼材料のみならずセラミ ックスも含めた焼結体の強度が, 気孔率に依存している ことはよく知られているが, ${ }^{11) ~ 13)}$ 今回の実験結果から研 削加工屑を用いた焼結体でも同様の傾向が認められた。

気孔率が $35 \%$ 以上の領域に注目すると, 曲げ強度と気 孔率との関係は焼結方法に依らず同一曲線上に位置する ことがわかる. 一方, 本研究と同様に PECS 法と VS 法 でアトマイズ鋳鉄粉を焼結した場合，気孔率 10 〜 $40 \%$ の領域ではVS 材の方が PECS 材よりも高い曲げ強度を 示すという報告例 ${ }^{10)}$ がある。 そしてこの強度差の原因と して内部の気孔形状の差（PECS 材の方が気孔形状が複 雑でかつ鋭利）によるものと説明している。しかし本研 究の場合, 気孔率 35 ～45\% の領域では, Fig. 2,3 に示 したように, 本研究の研削加工屑の場合明瞭な気孔形状 の差が現れないため，ほぼ同一の強度を示したと推察さ れる。

PECS 材の曲げ強度と気孔率との関係に注目すると， 気孔率の低下に対する曲げ強度の増加率は, 気孔率が小

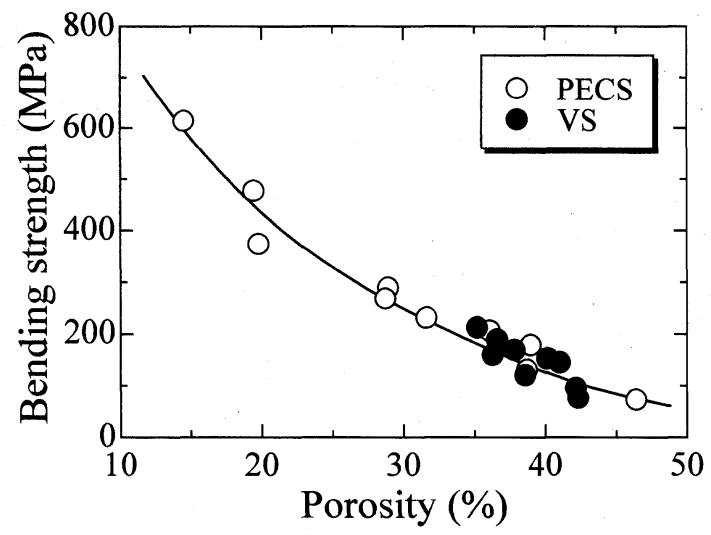

Fig. 8. The variation of the bending strength and processing temperature for PECS specimens.
さくなるほど大きくなり，アトマイズ鋳鉄粉と同様の傾 向を示す. 3・2 節でも述べたように, より高温, 高圧条 件で PECS 処理を行うことによってさらに高強度の材料 が得られることが推察される。

$\mathrm{VS}$ 法を適用した場合, $588 \mathrm{MPa}$ で成型後, $1400^{\circ} \mathrm{C} て ゙$ 真空焼結した試料でさえ $35 \%$ 以上の気孔率を有するた め, 曲げ強度は約 $200 \mathrm{MPa}$ にとどまり，VS 法では，高 密度化, 高強度化に限界があることがわかった。この原 因としては, 研削加工屑表面に存在する酸化皮膜が焼結 の進行を抑制するためと考えられる。

それに対して PECS 法を適用した場合は，気孔率は 15\%まで低下して高密度化が進むため, 曲げ強度 600 $\mathrm{MPa}$ 以上の高強度材が得られる。この緻密化の促進は, 柳沢ら ${ }^{2)}$ と村山 ${ }^{5)}$ が述べているように, 焼結時にバリア として働く表面酸化膜が PECS 焼結時には破壊されるた めと考えられる. 以上より, 研削加工屑の焼結方法とし て, VS 法より PECS 法が適しており, 研削加工屑は焼 結用素材としての使用できる可能性が高いことを示した.

\section{4 結 言}

ベアリング研削加工屑に対してパルス通電焼結法によ る固化成型を行い, 焼結体の密度，曲げ強度，組織とプ ロセス条件との関係について調査した。 その結果, 以下 のことを明らかにした。

（1）べアリング研削加工屑は，難焼結性材料である. すなわち, 従来法である真空焼結法による固化成型では 緻密化は難しく, そのため高強度材料の作製は極めて困 難である。

（2）パルス通電焼結法を適用することによって高密度 材料の作製が可能になり, 真空焼結材よりも高強度材の 作製が可能であることを示した。

(3) 研削加工屑に対する高密度固化方法としてパルス 通電焼結法が有効であること，ならびにべアリング研削 加工屑を焼結材の素材として利用できる可能性が高いこ とを示した。

\section{参 考 文 献}

1）平野陽之, “廃棄物処理・リサイクル事典” p.269（1995） 産調出版.

2) 柳沢 平, 畑山東明, 松木一弘, まてりあ, 33, 1489 (1994).

3 ）石崎幸三, 南口 誠, ニューセラミックス, 7, 39 (1994).

4) J. R. Groza, Scripta Metall., 30, 47, (1994).

5 ）村山宣光, セラミックス, 32, 445 (1997).

6) 大森 守, まてりあ, 39, 54 (2000).

7) 島田正雄, 素形材, 41-9, 8 (2000).

8 ）冨野寿和, 渡部 浩, 近藤祥人, 粉体およひ粉末治金, 44, 974 (1997).

9) 富野寿和, 近藤祥人, 勝村宗英, 東城哲朗, 粉体および粉 末治金, 45，703（1998）.

10）富野寿和, 近藤祥人, 勝村宗英, 東城哲朗, 粉体および粉 末冶金, 45, 715 (1998).

11) M. Eudier, Powder Metallurgy, 9, 278 (1962).

12) N. A. Fleck and R. A. Smith, Powder Metallurgy, 24, 121 (1981).

13) L. Bertini, V. Fontanari and G. Straffelini, J. Eng. Mater. and Techn. ASME, 120, 248 (1998). 